\title{
Behind Street Vendors Stall A Case Study on How Organizations Plays Role on Implementing Policies
}

\author{
Dani Mohammad Ramadhan \\ Faculty of Social and Political Sciences \\ University of Padjadjaran \\ Bandung, Indonesia. \\ danimohammadr@gmail.com
}

\author{
Rina Hermawati \\ Faculty of Social and Political Sciences \\ University of Padjadjaran \\ Bandung, Indonesia. \\ rina.antrop@gmail.com
}

\begin{abstract}
This paper aims to explain how various organization plays role on implementing policies among street vendors in Bandung, West Java, Indonesia. Using qualitative method with participant observation and structured in-depth interview as data gathering technique, the result shows that not only effectively articulating policies among street vendors, these organizations also have authority to negotiating policies.
\end{abstract}

Keywords: informal sectors; street vendors; organizations; policy implementation.

\section{INTRODUCTION}

On 17 December 2010, the Tunisian street vendor Mohamed Bouazizi burned himself to death in protest of the police's enduring, humiliating treatment of street vendors. He had been his family's main provider since he was ten years old. Selling fruits and vegetables on the streets of Sidi Bouzid, a rural town in central Tunisia, he was assaulted and harassed almost daily by local police officers who confiscated his goods and fined him for not possessing a permit. His self-immolation triggered the Tunisian Revolution, which not only led to the fall of then President Zine al-Abidine Ben Ali after a rule of twenty-three years, but also caused further revolts in numerous other Arabic-speaking nations, including Egypt, Libya and Syria. Nonviolent protest movements centrally located in public space also took place in Spanish, Greek, and eventually North American cities [1].

The Tunisian accident above shows us that street vendors are often seen as an obstacle by the government. But in the same time, they contribute in various aspect of our social economical life. Street vendors' contributions to urban life go beyond their own self-employment. They generate demand for a wide range of services provided by other informal workers, including transport workers, tea sellers, market porters, security guards, recyclers and others. They also generate demand for services provided by formal sector public and private actors, including transportation, and formal shops and suppliers from whom they source their goods. The Supreme Court of India has noted that, from a consumer point of view, street vendors "considerably add to the comfort and convenience of the general public, by making available ordinary articles of everyday use for a comparatively lesser price". This is a particularly important role for the urban poor who cannot afford to shop at supermarkets [2].

This phenomenon also occurs in Bandung, capital city of West Java Province. Confiscation, relocation, or demonstrations in the name of street vendors are often. Maybe not as extreme as Tunisian case does, but still, street vendors are the integral part of the social and economic life of Bandung. Through local regulation (Peraturan Daerah) No.4/2011. Local government of Bandung started to re-define and remanage the street vendors, mainly by the establishment of a Special Unit (Satuan Tugas Khusus or Satgasus) which headed by Vice Major and consist of many regional work unit related to street vendors.

Not only the establishment of Satgasus, in local regulation No.4/2011 also defining what street vendors is, and defining their classification based on type of products they selling, their trading time, and their place. This local regulation also mentioning the street vendors rights and obligations (street vendors ID ownership, cleanliness policy, etc).

On the implementation level, the street vendors in Bandung are not really knows the points inside the local regulation, but rather, there are organizations that have authority to control the street vendors in various locations in Bandung. Through this organization, the policies are reproduced and articulated to the street vendors, so if something wrong happens, the organizations stands up as the representation of the street vendors. This research focuses on how these organizations plays role in managing street vendors.

Corresponding author: Dani Mohammad Ramadhan 


\section{RESEARCH METHOD}

The research is in the inductive approach, the method we are using for this research is in qualitative manner by using participant observation and structured in-depth interview as data collection technique. We interviewed 10 organizations at period between July-August 2017. Every single informant is the head of their respective organizations. We also use informant triangulation, which means we check the validity of one informant data by asking it to other informants [3].

\section{RESULT AND DISCUSSION}

For convenience, in this result, we discuss the policy first, the organization second, including the implementation of the policy in organization context.

\section{A. The Policy}

As we mention above, the main regulation available to organize street vendors in Bandung is local regulation (Perda) No.4/2011. This regulation undergoes several changes in forms of revision and addendum, Mayor regulation (Perwal) No.888/2012 and Mayor regulation (Perwal) No.571/2014, the first is in the form of addendum regarding policy implementation, the second is in the form of revision of the main regulation (No.4/2011).

As an overview to the content of the local regulation No.4/2011, we already compile in a table below, substantial points of the regulations;

Table 1. Main Content of Local Regulation No.4/2011

\begin{tabular}{|c|c|}
\hline Point & Brief Description \\
\hline $\begin{array}{l}\text { The establishment of } \\
\text { street vendors Special } \\
\text { Task Force (Satgasus } \\
P K L)\end{array}$ & $\begin{array}{l}\text {-Headed by } \\
\text { Mayor. } \\
\text {-Consists of many } \\
\text { regional work unit } \\
\text { related to street } \\
\text { vendors } \\
\text {-This task force main } \\
\text { task is to plan, } \\
\text { arrange, control, } \\
\text { supervise } \\
\text { vendors (ex. Zero } \\
\text { growth, id making), } \\
\text { plus law } \\
\text { enforcements. }\end{array}$ \\
\hline $\begin{array}{l}\text { Street vendors } \\
\text { characteristics }\end{array}$ & $\begin{array}{l}\text {-Street vendors place to } \\
\text { sell should be easily } \\
\text { dismantled or moved. } \\
\text {-Street vendors are those } \\
\text { who use public }\end{array}$ \\
\hline
\end{tabular}

Table 1 Continued

\begin{tabular}{|c|c|}
\hline & $\begin{array}{l}\text { facilities such as roads } \\
\text { or pedestrians. }\end{array}$ \\
\hline $\begin{array}{l}\text { Street vendors } \\
\text { classifications }\end{array}$ & $\begin{array}{l}\text {-Based on merchandise, } \\
\text { time, and selling } \\
\text { locations. }\end{array}$ \\
\hline Zoning Policy & $\begin{array}{l}\text {-Consists of three zones } \\
\text { (red, yellow, and } \\
\text { green zone) } \\
\text {-Red zone is a location } \\
\text { where street vendors } \\
\text { are prohibited to } \\
\text { operate. } \\
\text {-Yellow zone is a } \\
\text { location where street } \\
\text { vendors can operate } \\
\text { depends on the } \\
\text { situation. is a } \\
\text {-Green zone is } \\
\text { location where street } \\
\text { vendors can operate. }\end{array}$ \\
\hline $\begin{array}{l}\text { Street vendors rights } \\
\text { and obligations }\end{array}$ & $\begin{array}{l}\text {-Including their } \\
\text { punishment for } \\
\text { disobeying the policy. }\end{array}$ \\
\hline
\end{tabular}

As for the revision and addendum, Mayor regulation No.888/2012 mainly mention about the implementation of the zoning policy in details, which street categorized as red zone, yellow zone, or green zone. Mayor regulation No.571/2014 on the other hand, mainly mention several changes in policy, such as grievance mechanism, obligations for street vendors, and of course, zoning.

\section{B. The Organizations}

The organization we talked about here is the street vendors organization which formed by themselves (grass roots) or each individual joins the existing one. These organizations usually establish based on their selling location or based on similarities of product that they sell. As for the organization type, many of them works informally which means it don't have hierarchy, flat and fluid. Some of them even operating ad hoc, which means the organizational parts will be seen and operate if something happens, for example in one case, one organization conduct fundraising for the victim of the natural disaster, someone is appointed as a treasurer for the particular event, whereas that person never been a treasurer before, except for the chairman of the organization. 
The role of the chairman in the organization is really crucial, he/she act as leader, spokesperson, or even manager, it is safe to say that many street vendor organizations in Bandung is a one-man organization. This practice, in our opinion, seems normal because each member has their own main role: as a seller, so no wonder why the structural hierarchy among street vendor organization isn't exist. The organization, act as street vendor guardian.

Because the organizations main role is to maintain security and convenience of street vendors while they operating, the role of the chairman is even more harder, not only lead and manage group of street vendor (internal function), he/she should have bargaining power against the authority (external function), mainly with Satpol PP (Civil Service Police Unit) -regarding public order-.

So, why each organization chairman should have bargaining power against the authority? Because at some point the street vendors can be unexpectedly against the rule, they did that because sometimes they feel unsatisfied with the policy. For example, at Tegallega streets at early August 2017, according to the regulation, categorized as red zone which in any case street vendors are prohibited to operate. The government had solution to move (relocate) groups of street vendors to operate inside Tegallega park. Because of the declining income, street vendors are disobeying the rule and operating again in Tegallega main streets, money talks. By doing this, they against the rule, many vendors are confiscated. In this part, the organization chairman acts as catalyst/mediator between Satpol PP and the seller who break the rules.

The aftermath, -from data that we receive- now street vendor are able to sell their product at Tegallega streets after 6 PM. It is unofficially become yellow zone.

Looking at the case above, there are 2 opposite order, on the one hand, government, in the name of public order, have to organize street vendors. On the other hand, street vendors are dealing with their subsistence needs, these subsistence needs had to compromise with rules and regulations, which can be compromised later by their participation on one organization. In exchange, they have to pay "sort of" tributary money. We said "sort of" because when we asked, the money is for cleanliness or security dues, God knows where the money went. The amount of money they have to pay is approximately Rp.5000Rp.10000.

Every organization are worked just the same, they exist to make their member safe while selling. But in governments view, the presence of these organizations is advantageous because they can be easily monitors street vendors, remember, one of their goals in local regulation No.4/2011 is zero growth. When it comes to the relation among organizations, interesting thing happens.

As we mentioned above, street vendor organizations managed by mainly one person, that is, the chairman of the organization. This chairman should have authority to solve whether internal problems or external problems (bargaining power). Specifically, at solving external problems where they have to deal with governments, the person chosen as chairman should not just an ordinary person, he should have inner relation with the government or have "place" in the government, in other words, a respectable person that accepted by these two "worlds"; street vendors and government. In this point of view, organizations are just aggregate of "respectable" person.

This aggregate of respectable person inside organizations are knows each other, but in an uneasy relationship. They tend to dominate each other. Currently, there is one person/organization that dominating many, almost every street vendor organizations, let's say this organization; X organization.

In order to expand, this $\mathrm{X}$ organization gains control over other organization by helping them solving the problems. Expectedly, this one person in this $\mathrm{X}$ organization has closer relationship compared to another chairman. By joining with $\mathrm{X}$ organization, does not disband the other organization, the chairman becomes X organization "working area" coordinators, while still become chairman of their respective organization.

\section{CONCLUSION}

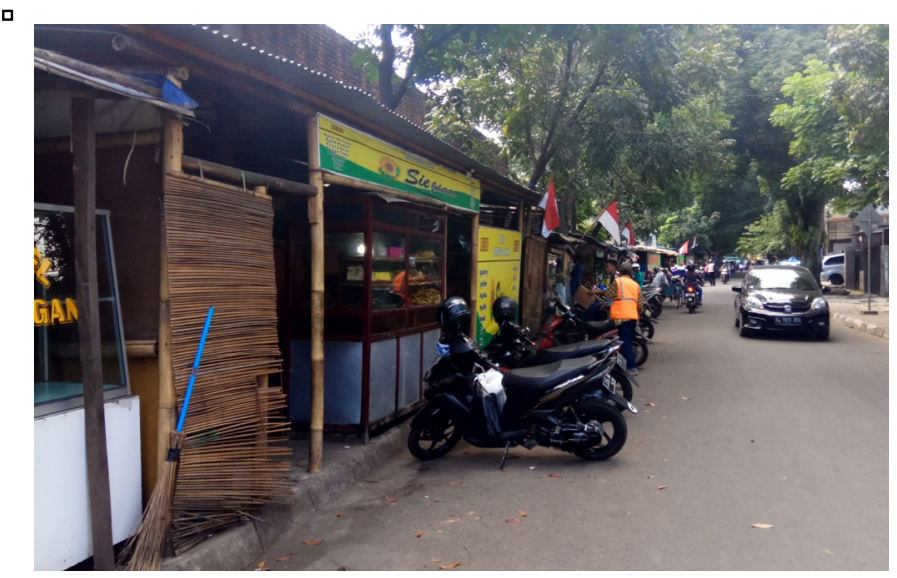

Picture 1. An array of semi-permanent street vendors at Balonggede Street, Bandung (personal documentation).

As the term implies, informal economy is the part of economy where it is not recorded or contribute to the nation GDP. ILO describe that informal economy 
has distinguished characteristics, in short, low quality jobs as part of increasing poverty. Street vendor is the part of it.

As the easy alternative for many persons to prevent poverty, street sellers are often having a low understanding regarding the policy surrounding street vendor practice.

Organizations and the man behind it are present as catalyst between street sellers that their main goal is to "sell" for their substantive needs, and governments which their main goal is to create public harmony. In order to bridge those worlds, the organizations, whether want it or not, has to negotiate public policy, and constantly articulating the rules to the street vendors.

\section{ACKNOWLEDGEMENT}

We would like to thank Mr. Iwan Suhermawan for his tremendous help in this research, and also all of the informants who are willing to share their story.

\section{REFERENCES}

[1] J. K. Graaff, \& N. Ha, Street Vending in The Neoliberal City (A Global Perspective on the Practices and Policies of a Marginalized Economy). New York: Berghahn Books. 2015.

[2] S. Roever, \& C. Skinner. Street Vendors and Cities. Environment \& Urbanization: SAGE Journals , 2016, pp. 116.

[3] N. K. Denzin, \& Y. S. Lincoln, Collecting and Interpreting Qualitative Materials. London: Sage Publications. 2012. 